\title{
METAFORY W SŁUŻBIE BUDOWANIA TOŻSAMOŚCI. KRYTYCZNA ANALIZA DYSKURSU JAKO NARZĘDZIE BADANIA DYSKURSU KATOLICKIEGO NA TEMAT MNIEJSZOŚCI HOMOSEKSUALNEJ I ZWOLENNIKÓW TEORII GENDER (NA PRZYKŁADZIE MEDIALNYCH WYPOWIEDZI DARIUSZA OKO)
}

\begin{abstract}
Kościańczuk Marcela, Metafory w stużbie budowania tożsamości. Krytyczna Analiza Dyskursu jako narzędzie badania dyskursu katolickiego na temat mniejszości homoseksualnej i zwolenników teorii gender (na przykładzie medialnych wypowiedzi Dariusza Oko) [Metaphors as the Tools of Creating Identity. Critical Discourse Analysis as a Method of Interpretation Dariusz Oko's Discourse About the Homosexual Minority and Gender Studies Scholars]. Studia Edukacyjne nr 41, 2016, Poznań 2016, pp. 307322. Adam Mickiewicz University Press. ISSN 1233-6688. DOI: 10.14746/ se.2016.41.19

The article presents an analysis of Dariusz Oko's articles about the homosexual minority and people who are gender studies' scholars or supporters. It shows metaphors and comparisons as tools of creating identity and ideological discourse. Narration is analyzed according to Critical Discourse Analysis tools. I present the re-scalation mechanism and compare Dariusz Oko's rhetorical tools against envious prejudice.
\end{abstract}

Key words: critical discourse analysis, gender studies, homosexuality, discrimination

\section{Wstęp}

Krytyczna Analiza Dyskursu (KAD) jest interdyscyplinarną metodą analizy i interpretacji wszelkich informacji, jakie istnieją $\mathrm{w}$ obiegu publicznym i wywierają wpływ na kształtowanie się poglądów jednostek oraz grup społecznych. Metoda ta łączy osiągnięcia lingwistyki oraz socjologii, by wskazać na przestrzenie przenikania się mechanizmów narracyjnych i reakcji 
społecznych. Jak piszą Norman Fairclough i Anna Duszak, do zasadniczych zadań KAD należy zrekonstruowanie relacji wpływających na: „powstawanie, konsolidację, transformację zjawisk społecznych"1. Poprzez dokonywanie rozwarstwienia i dogłębnej analizy struktur, ukierunkowanych na wywieranie społecznego wpływu, przez odwołania do mechanizmu stosowania zmiennych i restrukturyzowanych skal (np. globalnej i lokalnej, jednostkowej zamienianej ze społeczną czy ogólną), można docierać do sposobów zmiany postrzegania zjawisk społecznych, a ostatecznie także do zmiany samych tych zjawisk².

Kluczową kwestią dla Krytycznej Analizy Dyskursu jest także dostrzeganie wzajemnych zależności pomiędzy komunikowanymi mechanizmami władzy i podporządkowania. Wspomniane mechanizmy mogą wpływać na odbiorców, nie tylko za pomocą tradycyjnie analizowanych kanałów lingwistycznych, takich jak słowo mówione czy pisane, ale także poprzez informacje wizualne, czy ponadwerbalną sieć odniesień (np. sposoby artykulacji, mimikę twarzy, gesty, intonację, ale także kontekst wypowiedzi) ${ }^{3}$.

Dyskurs będący przedmiotem poniższej analizy stanowi każdy komunikat, który jest analizowany w odniesieniu do strukturalistycznie wyróżnionych aspektów langue i parole ${ }^{4}$ a więc do elementów systemowych i tych stanowiących indywidualne bądź społeczne inwariantne formy odniesienia do systemu. Z punktu widzenia socjologicznego ukierunkowania KAD te ostatnie są szczególnie istotne.

Artykuł stanowi próbę odniesienia narzędzi wypracowanych na gruncie Krytycznej Analizy Dyskursu do wypowiedzi medialnych na temat homoseksualności i teorii gender jednego z przedstawicieli dyskursu konserwatywnego i katolickiego - księdza Dariusza Oko. Celem jest tu wskazanie na różne płaszczyzny systemowych odniesień tych wypowiedzi oraz wykazanie zjawiska re-skalowania, a więc dyskursywnego przenoszenia zjawisk na różne poziomy odniesienia. Analiza dąży do odnalezienia powiązania pomiędzy zasadniczymi ideologicznymi a tożsamościowymi celami wskazanego dyskursu.

${ }^{1}$ A. Duszak, N. Fairclough (red.), Krytyczna analiza dyskursu. Interdyscyplinarne podejście do komunikacji społecznej, Kraków 2008, s. 8.

2 Jeśli przyjmiemy proklamowane przez konstruktywizm założenie, iż jedyną dostępną badaniu rzeczywistością jest interpretacja rzeczywistości, gdyż nie mamy dostępu do innej rzeczywistości „samej w sobie” bądź też ona w ogóle nie istnieje.

${ }^{3}$ Intonacja czy sposób artykulacji wiażą się z werbalnością, ale przekraczają ją, odnosząc się do dodatkowego czynnika semantycznego, dlatego też wspomniane odniesienia zostały nazwane ponadwerbalnymi, a nie pozawerbalnymi.

${ }^{4}$ N. Fairclough, Language and power, Essex 1989, s. 20-22. 
Ponieważ temat ten jest niezwykle obszerny, ograniczyłam analizę niemal wyłącznie do perspektywy użycia środków poetyckiego obrazowania, w wypowiedzi publicystycznej, ze szczególnym uwypukleniem retorycznej i tożsamościowej funkcji metafor, odwołujących się do hybrydycznie połączonych perspektyw - historycznej, politycznej, ekonomicznej i religijnej. Jak wskazuje Phil Graham, hybrydyczność jest charakterystycznym elementem dyskursu w obrębie wielu wypowiedzi ideologicznych ${ }^{5}$.

Odwołując się do teorii Louisa Althussera (teoretyka pojęcia ideologii oraz jednego z badaczy, do których nawiązuje przyjmowana na gruncie tych rozważań Krytyczna Analiza Dyskursu), analizowane tu teksty należą do wypowiedzi zaklasyfikowanych do prywatnej domeny ideologicznego aparatu państwowego, z punktu widzenia teorii Louisa Althussera ${ }^{6}$, do których nawiązuje przyjmowana na gruncie tych rozważań Krytyczna Analiza Dyskursu.

Ideologia jest tu postrzegana jako reprodukcja świadomości i kwalifikacji siły roboczej, czyli dyskurs ideologiczny jest nastawiony na utrzymywanie spójnego poglądu określonej grupy społecznej. Pogląd ten, czy raczej zestaw poglądów, ma (na gruncie tej perspektywy) utrzymywać posłuszeństwo i w pierwotnym sensie sprzyjać wydajności i kwalifikacji pracowników. W ideologiach systemów prywatnych (przeciwstawianych państwowemu, którego naczelnym mechanizmem działania nie jest ideologia, ale represje), do których obok wypowiedzi związanych z dyskursami różnych kościołów należy także dyskurs ekonomiczny, prawny, szkolny, czy artystyczny, istnieje w przekonaniu Althussera bliski, choć pośredni model wykształcania posłusznego pracownika, obywatela, czy ucznia. Posłuszeństwo jest tu istotną wartością, która może być w rozmaity sposób strzeżona na gruncie językowym (głównie retorycznym). Zarówno Fairclough, jak i Althusser zwracają uwagę, że dyskurs ideologiczny ma znaczenie w utrzymywaniu stałości grup klasowych lub staje się proklamacją przemian w obrębie uwarunkowanych społeczno-ekonomicznie grup ${ }^{7}$.

W kontekście analizowanego tematu można by zastanawiać się nad kształtowaniem określonego typu dyskursu, który ma na celu utrzymanie spójności grupy religijnej, przedstawionej w opozycji wobec rzeczywistych

\footnotetext{
5 Ph. Graham w: A. Duszak, N. Fairclough (red.), Krytyczna analiza dyskursu, s. 51-53.

${ }^{6}$ L. Althusser, Positions, Paris 1976 (polski przekł. A. Staroń na łamach internetowego czasopisma: http://www.nowakrytyka.pl/spip.php?article374, 2010).

7 Tamże; N. Fairclough, Analysing Discourse Textual Analysis for social research, London New York 2003, s. 5.
} 
lub imaginacyjnych przedstawicieli innych poglądów ${ }^{8}$. Odnosząc się jednak do stanowiska Althussera, można wskazać, że częste pojawianie się tego tematu $\mathrm{w}$ mediach katolickich oraz $\mathrm{w}$ innych mediach przez przedstawicieli publicystów czy „ekspertów” katolickich świadczy o świadomości przemian społecznych, które mogą być postrzegane przez przedstawicieli określonej grupy religijnej jako wyzwanie, któremu można nadać określony sens etyczny, a także tożsamościowy. Zmiana społeczna może stanowić wyzwanie dla zastanej struktury, ale także stanowić element umocnienia się tożsamości w oporze przeciw zjawisku postrzeganemu jako „wrogie” czy w słabszym sensie niekorzystne.

\section{Konsumpcja jako laicyzacja}

Metafory używane $\mathrm{w}$ tekstach księdza Dariusza Oko można przyporządkować do kilku grup. Pierwszą, wyróżnioną przeze mnie, kategorią są te, które odwołują się do perspektywy biznesowej, marketingowej, czy w pewien sposób do kategorii ekonomicznych (materialnych). Jak się wydaje $\mathrm{w}$ odniesieniu do szerszej skali (biorąc pod uwagę nie tylko analizę w dyskursie, ale i nad dyskursem, co proponuje Krytyczna Analiza Dyskursu) ${ }^{9}$, można zauważyć, że wybór tego rodzaju metaforyki może odwoływać się do krytyki konsumpcjonizmu, wyrażanej przez dokumenty kościelne. Oczywiście, nie każda metafora powiązana z perspektywą marketingową musiałaby od razu odnosić się do perspektywy konsumpcjonistycznej, która

8 We wskazanych wypowiedziach homoseksualiści przedstawiani są jako spójna grupa społeczna. Faktycznie jednak trudno powiedzieć o spójności światopoglądowej osób identyfikujących się z określoną orientacją seksualną. W Polsce istnieje na przykład grupa Wiara i Tęcza, która zrzesza religijne osoby LGBTQ, wśród których większość stanowią katolicy. Z tego względu należy zauważyć, że przynajmniej część przedstawicieli środowisk LGBTQ może podzielać wiele poglądów reprezentowanych przez instytucję Kościoła rzymskokatolickiego. Dlatego, użyłam sformułowania stwierdzającego, że grupa ta może być jedynie przedstawiana jako opozycyjna wobec stanowiska religijnego czy też reprezentowanego przez określoną wyżej instytucję religijną. Drugą kwestią jest także, kształtowana przez analizowanego autora, koncepcja nie w pełni jasnej granicy między częścią środowiska kościelnego a przedstawicielami grupy nazywanej przez Dariusza Oko „homoseksualnym lobby". Jak zauważa autor, w obrębie instytucji kościelnych także znajdują się osoby nie będące w świetle tej koncepcji "prawdziwie” przedstawicielami tejże instytucji. Kwestię tę omawiam szerzej w dalszej części artykułu.

${ }^{9}$ Analiza w dyskursie zajmuje się jedynie egzemplarycznymi przykładami, natomiast analiza nad dyskursem dotyka także kwestii systematycznych powiązań konkretnych przykładów z szerszymi odniesieniami ideologicznymi czy teoretycznymi. A. Duszak, N. Fairclough (red.), Krytyczna analiza dyskursu, s. 17. 
zyskuje negatywne odniesienie etyczne, jednak biorąc pod uwagę zjawisko re-skalacji, a więc przeniesienia terminów z gruntu egzystencjalnego czy perspektywy antropologicznej lub socjologicznej (jak można byłoby określić analizowane tu kwestie zachowania się osób identyfikujących się z określoną orientacją seksualną) na grunt marketingowy, nawiązuje retorycznie do pewnego rodzaju etycznej waloryzacji. Także konkretne użycie takich terminów, jak homo-lobby ${ }^{10}$, promocja homoseksualizmu („Od dłuższego czasu jesteśmy w Polsce świadkami oraz celem promocji homoseksualizmu") ${ }^{11}$, czy pełen pakiet postulatów („Trzeba pamiętać, że homozwiązki pociągają za sobą cały pakiet. Jeśli zgodzimy się na homozwiązki, to niebawem dojdzie do tego adopcja, zaraz później przyjdzie nakaz mówienia 'rodzic A' i 'rodzic B' zakaz mówienia 'mama' i 'tata'"12) odwołują się do zmiany rejestru kontekstu, z narracji dotyczącej jednostki lub grupy ludzi na rzecz perspektywy przedmiotowej, odnoszącej się do grup interesów bądź usług.

Konsumpcjonizm oraz "promocja własnego ja” są w dokumentach kościelnych jednoznacznie krytykowane i łączone $z$ hedonizmem oraz laicyzacją. Przykładami stwierdzeń, które odnoszą się do konsumpcjonizmu w ten sposób są choćby encyklika Caritas in veritate czy list Novo millenio inneunte. W tym pierwszym dokumencie czytamy o hedonizmie i konsumpcjonizmie jako postawach, ku którym skłania się wiele społeczeństw, obojętnych na powstające pod wpływem tych postaw szkody ${ }^{13}$, w drugim możemy przeczytać o wewnętrznych problemach instytucji kościelnej, które wynikają $\mathrm{z}$ „wyjałowienia konsumpcjonizmem” i laicyzacją ${ }^{14}$.

Metaforyka związana z konsumpcjonizmem, w odniesieniu do społeczności homoseksualnych, ma za zadanie powiązanie postaw życiowych z perspektywą materialną, przedmiotową, sprzeciwiającą się etyce katolickiej, a nawet zagrażającą tejże. Kontekst użycia przywołanych sformułowań

10 Termin lobbing nie jest bezpośrednio powiązany z perspektywą marketingową, jednak dotyczy nieuczciwych praktyk zmierzających do osiągnięcia własnych korzyści określonej grupy odbiorców i często rozpatruje się go jako przykład nieuczciwej strategii biznesowej, mającej też duże związki ze światem polityki. M.M. Wiszowaty, Regulacja prawna lobbingu na świecie. Historia, elementy, stan obecny, Warszawa 2008.

11 D. Oko, Dziesięć argumentów przeciw, „Gazeta Wyborcza” z 28-29 maja 2005, s. 27.

12 D. Oko, Homolobby przypisuje sobie cechy boskie, http://www.fronda.pl/a/ks-oko-dlafrondapl-homolobby-przypisuje-sobie-cechy-boskie,26501.html [dostęp: 18.3.2013].

13 Benedykt XVI, Encyklika Caritas in veritate Ojca Świętego Benedykta XVI do biskupów, prezbiterów, diakonów, do osób konsekrowanych i wszystkich wiernych świeckich o integralnym rozwoju ludzkim w miłości i prawdzie, Kraków 2009.

14 Jan Paweł II, List apostolski Novo millennio ineunte Ojca Świętego Jana Pawła II do biskupów, duchowieństwa i wiernych na zakończenie wielkiego jubileuszu roku 2000, Kraków 2001, paragraf 46. 
nawiązuje nie tylko do informowania o tym, że akt homoseksualny jest sprzeczny z nauką Kościoła i przeczy wartościom ważnym dla określonego środowiska. Większość stwierdzeń uwypukla rodzaj zagrożenia związanego z "promocją" homoseksualizmu czy działalnością "homolobby”. Przykładami zdań wskazujących na konsumpcjonistyczną groźbę są między innymi zdania: „jesteśmy celem promocji homoseksualizmu”, czy pochodzące $\mathrm{z}$ tego samego artykułu zdanie: "Ofensywę homoseksualizmu trzeba widzieć w szerszym kontekście ogólnej dekadencji, jako element procesów negatywnej dechrystianizacji, laicyzacji i ateizacji społeczeństwa konsumpcyjnego"15.

W hybrydyczną jedność połączyły się opozycyjny wobec idei autora zestaw poglądów, konsumpcjonistyczno-ateistyczne przekonania oraz przemoc, określana tu przemocą symboliczną czy ideologiczną. Wskazuje na to fragment wypowiedzi publicystycznej Dariusza Oko, gdzie wskazuje, że nie tylko mniejszość homoseksualna, ale także "genderowcy" (których utożsamia on ze zwolennikami „ideologii homoseksualnej”) stanowią bezpośrednie zagrożenie dla katolików: „(Genderowcy) Stosują przemoc - nie zbrojną, ale ideologiczną"16.

Wskazane cytaty odwołują się do poczucia zagrożenia i bezpośredniego wpływu wywieranego przez środowisko homoseksualne na społeczność katolików. W przekonaniu autora oraz budowanej przez niego narracji dostrzegamy tożsamość kilku światopoglądów, które są w tym dyskursie ze sobą połączone tak, że właściwie nie można ich rozróżnić. Jednym z tych dyskursów jest narracja konsumpcyjna, równoznaczna $\mathrm{z}$ ateistyczną i wrogą religijności. Topika walki współwystępuje tu ze spectrum odniesień konsumpcyjnych. Faktycznie jednak to te ostatnie odniesienia mogą wskazać na budowanie $\mathrm{w}$ wypowiedzi dualistycznego schematu o charakterze manichejskim. Media, świat finansowy i polityka są tutaj jednym konglomeratem, nawiązującym do tego samego pola semantycznego. Są one utożsamiane przez Dariusza Oko z mechanizmami „przemocy wyższego rzędu”, które mogą do pewnego stopnia przypominać koncepcję Michela Foucaulta, który jednak, jak się ostatecznie okazuje, dochodzi do zupełnie innych konkluzji niż autor analizowanych wypowiedzi.

${ }^{15}$ D. Oko, Dziesięć argumentów przeciw, s. 27-28.

16 D. Oko, Genderrewolucja, „Polonia Christiana” z marca/kwietnia 2013, http://www.pismo. poloniachristiana.pl/Genderrewolucja,33,0,996,1,PCH,numer.html [dostęp: 18.3.2001]. 


\section{Dychotomia ciała i ducha. Dyskurs medykalno-teologiczny}

Michel Foucault dostrzegał, że na przełomie XVIII i XIX wieku w historii kultury nastąpiła zmiana $\mathrm{w}$ interpretowaniu strategii dyscyplinujących. O ile we wcześniejszych okresach tortury cielesne oraz wszelkie inne mechanizmy związane $\mathrm{z}$ unieruchamianiem ciała stanowiły praktyki karania tych, którzy zdecydowali się przekroczyć normę, o tyle przełom oświeceniowy przyniósł inny stosunek do kary, związany z internalizacją poczucia kontroli i reżimu. Tego typu działania pozwalają na kontrolę psychiki czy ducha ludzkiego jedynie pośrednio, odwołując się do ciała jako podmiotu wymagań moralnych. Foucault przedstawia wizję panopticonu, przestrzeni więziennej skonstruowanej tak, że osoby osadzone nie są pewne tego, w którym momencie podlegają kontroli. Zdają sobie sprawę, że w każdej chwili mogą być obserwowane ${ }^{17}$.

W przekonaniu Dariusza Oko, to media, świat finansów i polityka stają się Foucaultowskim panopticonem, służącym jednakże nie tyle do dyscyplinowania ducha $\mathrm{w}$ kierunku wypełniania jakiś norm, co raczej sprzeciwiania się uznanym i, w przekonaniu publicysty, słusznym zasadom oraz wartościom $^{18}$. Tym samym, władza mediów, biznesu i polityki (stopiona wizją jedności lobbujących grup powiązanych $\mathrm{z}$ tymi trzema przestrzeniami odniesień) kultywują promocję „użycia ciała” wbrew ideom dążącym do regulacji zachowań cielesnych (ascezy, czystości, celibatu, umiarkowania). Możemy zauważyć, że dostrzeżenie podobnego mechanizmu, związanego ze zmianą strategii przemocy społecznych aparatów, prowadzi polskiego i francuskiego filozofa do zupełnie odmiennych wniosków.

Wielokrotne nawiązania $\mathrm{w}$ (dotyczących homoseksualności) tekstach Dariusza Oko do powiązanego z przeciwnikami światopoglądowymi hedonizmu zdają się budować perspektywę dualistyczną, w której wrogiej i przynoszącej zgubę przestrzeni materialnej przeciwstawiana jest druga, inna przestrzeń, reprezentowana przez wartości katolickie, będące nieustannie w stanie zagrożenia. Media, polityka i biznes są zatem po stronie hedonistycznego obrazu ciała, a zbiór wartości katolickich - po stronie ducha i pozytywnie waloryzowanej etyki umiarkowania. $\mathrm{W}$ tej dualnej perspektywie po stronie mediów, polityki i biznesu znajduje się także homoseksualizm, który nie jest tu przedstawiany jedynie jako jedna z orientacji

17 M. Foucault, Nadzorować i karać. Narodziny więzienia, Warszawa 1998.

18 Oczywiście Michel Foucault należy do grona autorów, którzy są objęci negatywnym wartościowaniem przez analizowanego publicystę, toteż nie można mówić o bezpośrednim odwołaniu się autora tekstu do poglądów francuskiego filozofa. 
seksualnych, ale raczej zinterpretowany jako element kultury sprzeciwiającej się katolicyzmowi. Wskażmy na cytaty, które stają się źródłem mojej analizy.

Dla zdrowego rozumu akceptacja homoseksualizmu jest oczywiście nie do przyjęcia. Jednak człowiek, jeśli się uprze, może do końca życia bronić dowolnego absurdu. (...) Homoseksualiści ponadproporcjonalnie do swej liczby przyczynili się do wybuchu epidemii AIDS. (...) Nie powinien dziwić fakt, że poza samymi homoseksualistami sąosoby popierające ich wybory. Ileż to już razy nawet większość była w błędzie, negując przy tym zupełnie Boga i Kościół (... $)^{19}$.

Telewizja Publiczna jest przecież tworzona za pieniądze publiczne, całego społeczeństwa i jemu całemu ma służyć, a nie tylko jakiejś wąskiej grupie interesów. Telewizja ma równomiernie, sprawiedliwie reprezentować różne stanowiska, a to była raczej homopropaganda. Społeczeństwo polskie w zdecydowanej większości jest przeciwne zrównaniu homozwiązków z małżeństwem i homoadopcję, a wczoraj było reprezentowane jako mniejszość. I podobnie jest prawie we wszystkich takich programach. Mógłby ktoś zapytać, po co my w ogóle jesteśmy zapraszani do takich programów. Chyba jedynie po to, by uczynić nas obiektem zaszczucia (...) Proponuję powołać komisję i zbadać, ilu wśród chorych na choroby zakaźne czy wśród pedofilów jest homoseksualistów. Pójdźmy razem do polskich szpitali zakaźnych oraz więzień i policzmy, ustalmy proporcje. Tylko czy ktoś z moich oponentów zdecyduje się na takie badania? Oczywiście, że nie, uciekają przed prawdą, ideologowie przeżywają paniczny strach przed twardą rzeczywistością, która obala ich iluzje. Jeżeli homoseksualistów jest mniej więcej 2 proc. w społeczeństwie, a jest ich około 40 proc. wśród pedofilów i 60 proc. wśród chorych na AIDS, to znaczy to, że kilkadziesiąt razy częściej stają pedofilami i chorują na AIDS (oraz na inne choroby weneryczne). Wynika to $\mathrm{z}$ niesłychanego, niespotykanego nigdzie indziej promiskuizmu, rozpusty, w jakich żyją²0.

Po jednej stronie jest "choroba rozumu”, wybory sprzyjające epidemii poważnej choroby, błąd i zupełna negacja Boga oraz instytucji Kościoła, po drugiej - zdrowie i normy religijne oraz te odwołujące się do obiektywnego rozumu. Powiązane są tu ze sobą określenia odwołujące się do perspektywy biologiczno-medykalnej (wskazujące na kontinuum zdrowia i choroby), zwrot $\mathrm{ku}$ racjonalności i noramatywny kodeks instytucji religijnej (oraz przyjętego prawa ponadnaturalnego). W drugim analizowanym fragmencie możemy dostrzec bezpośrednie wskazanie na mniejszość, która jest źródłem "zaszczucia” większości. Arjun Appadurai wskazuje, że dyksursy, które

19 D. Oko, Homoseksualizm nie jest norma, "Gość Niedzielny”, 2009, 37 http://gosc. pl/doc/788663.Homoseksualizm-nie-jest-norma [dostęp: 13.4.2013].

20 Tekst dotyczy programu Tomasza Lisa, do którego został zaproszony ksiądz Dariusz Oko, który w jego przekonaniu nie miał równego prawa głosu w odniesieniu do innych osób występujących w programie. D. Oko, Homolobby przypisuje sobie cechy boskie, http://www. fronda.pl/a/ks-oko-dla-frondapl-homolobby-przypisuje-sobie-cechy-boskie,26501.html [dostęp: 18.3.2013]. 
przedstawiają ilościowo słabszą grupę jako źródło zagrożenia są wyrazem tożsamości drapieżczych (budujących swoje odniesienia tożsamościowe na budzeniu lęku wobec mniejszości). Są one kreowane przez grupy niepotrafiące odnaleźć własnego miejsca w zglobalizowanej rzeczywistości, która przynosi destabilizację dawnych norm, oferując wizję atomizacji społecznej, utraty bliskości, bezpieczeństwa i stabilności ${ }^{21}$. Ponieważ jednak występowanie przeciw globalizacji nie ma sensu (dopóki nie wskaże się jej twórców), obiektem zastępczym stają się mniejszości, a zwłaszcza figura nazwana przez Appaduraia „ciałem umniejszościowionym"22, czyli medykalnobiologiczne odniesienie do grup mniejszościowych.

\section{Metaforyka wrogiego świata}

Teksty Dariusza Oko uwypuklają wizerunek negatywnej, zagrażającej rzeczywistości upadku wartości. Pozytywna wizja, powiązana ze sferą postulowanych wartości jest dużo mniej podkreślona. Pozytywni bohaterowie tekstu nie występują $\mathrm{w}$ oddzieleniu od ich wrogów. We wspomnianym jako ostatni artykule dotyczącym "Genderrewolucji”, 80\% treści tekstu dotyczy opisu grup sprzeciwiających się światopoglądowi katolickiemu. Trudno w artykułach Dariusza Oko odnaleźć metaforykę, która nie odwoływałaby się do konfrontacji, czy opozycji, częstokroć wyrażanej w języku hiperboli i uogólnienia (niekiedy synekdochy), dotyczącej wymienionej powyżej sfery materialności, cielesności, odwołującej się do konsumpcjonizmu, hedonizmu. Dariusz Oko tworzy także specyficzne określenia, epitety będące etykietami językowymi, którymi posługuje się dość konsekwentnie w swoich tekstach. Ewentualna dyskusja z autorem musiałaby zatem odwoływać się najpierw do uzgodnienia podstawowych terminów z tak zwanego rortiańskiego słownika finalnego ${ }^{23}$ obu rozmówców.

${ }^{21}$ D. Oko, Homolobby.

22 A. Appadurai, Strach przed mniejszościami. Esej o geografii gniewu, przekł. M. Buholc, Warszawa 2009, s. 52.

${ }^{23}$ Poprzez słownik finalny amerykański filozof rozumie zestaw specyficznych pojęć i konstrukcji zdaniowych, używanych przez interlokutorów w celu poparcia swojego stanowiska. Słowniki finalne można analizować w wymiarze idiolektycznym, czyli odwołując się do indywidualnych, tworzonych przez każdego człowieka, odmian mowy. Odgrywają one jednak bardzo dużą rolę $\mathrm{w}$ procesach związanych $\mathrm{z}$ ideologizacją i stanowią narzędzie propagandowe dla większości systemów. W pewnej mierze idiolekty jednostkowe są zależne także od wspomnianych mechanizmów systemowych. W analizowanym przypadku wskazuję na elementy słownika finalnego jednego $\mathrm{z}$ autorów jako przykład konstruowania narracji obecnej $\mathrm{w}$ mediach katolickich czy też jednego z dyskursów instytucji religijnej. R. Rorty, Ironia, przygodność i solidarność, przekł. W.J. Popowski, Warszawa 1996, s. 107-115. 
Do wspomnianego słownika autora należą zwroty specyficznie określające jego przeciwników światopoglądowych. Na przykładzie wspominanego, analizowanego artykułu, pochodzącego z "Polonii Christiany”, dostrzegamy, że gender ideologia (obecna pięć razy) i "genderowcy" (cztery razy), trzy razy występuje także określenie genderrewolucjoniści oraz raz gendertotalitaryzm (Dariusz Oko nazywa również przynajmniej niektórych „animatorów seksualnej rewolucji" zwyrodnialcami i szaleńcami). Wszystkie określenia dotyczą jednej grupy osób, przeciwstawionej głównej bohaterce tekstu (Gabriele Kuby, której nazwisko jest wymienione 8 razy, w tym raz w tytule i raz w posłowiu, wskazującym na konieczność przetłumaczenia jej książki na język polski). Zastosowano tu retoryczną technikę, w ramach której jednostce przeciwstawiana jest niezwykle groźna i w logice tekstu niezwykle wpływowa grupa osób (Oko wymienia przykłady, z których można wywnioskować, że genderowcy, wśród których z nazwiska wymieniona jest m.in. Judith Butler i Alfred Kinsey, ale możemy też przeczytać, że genderowcy zdominowali władze Unii Europejskiej).

Przedstawiając ateistów jako wielką grupę, w obrębie której przedstawiciele koncepcji genderowych stanowią podzbiór, Dariusz Oko pisze:

Trzeba pamiętać, że największe zbrodnie w dziejach świata, wielokrotnie przerastające wszelkie inne, popełniali ateiści. Pol Pot, Mao Tse Tung, Hitler, Lenin, Stalin. Ich zbrodnie przewyższają wszelkie inne. To nie jest przypadek, to wynika z wewnętrznej logiki ateizmu. Kłamstwo, pogarda, agresja i nienawiść obecne w ideologii gender to tylko mała część czegoś o wiele większego, czegoś odwiecznego24.

Obydwie grupy (ateiści i zwolennicy gender studies) są tu zestawione na prawach analogii z totalitarnymi oraz autorytarnymi liderami i, jak sam Oko wskazuje, „zbrodniarzami”, służącymi odwiecznemu, ponadświatowemu złu. Ateizm nie jest tu przedstawiany jedynie jako zjawisko socjologiczne, nie jest on tak zwanym faktem społecznym. Zjawisko to jest raczej teologizowane i ujmowane jako element swoistej ponadczasowej walki sił dobra i zła.

Przykład dualnej logiki, w której zło jest uosobione w postaci grupy mniejszościowej, daje zacytowany poniżej fragment publicznej wypowiedzi (wywiadu dla portalu Fronda.pl). Dariusz Oko wyraźnie wskazuje zwolenników teorii gender oraz homoseksualistów jako współczesnych nazistów. Jedyną różnicą między nazistami i zwolennikami praw dla homoseksualistów jest, wedle Dariusza Oko, fakt, iż naziści urzeczywistnili swoje plany, natomiast mniejszości dopiero planują je urzeczywistnić. Retoryka ostrzeże-

24 D. Oko, Homolobby. 
nia przed planowanym zagrożeniem ma większą moc perswazyjną niż relacjonowanie rzeczywistych sytuacji. Pomimo tego, że Oko nie wskazuje na żadne realne fakty, a jedynie na niezidentyfkowane pomysły, idee, czy plany, to jednak autor przedstawia wspomniane idee tak, jakby były faktami dokonanymi, posługując się trybem oznajmującym, a nie przypuszczającym.

Dodatkowo można dostrzec tu mechnizm budowania spójnej, chronologicznej narracji, która przypomina do złudzenia wypowiedź o faktach. W pierwszym zdaniu wskazywanej poniżej wypowiedzi Oko mówi o planach budowy gett dla (określanych stosunkowo neutralnie) „przeciwników gejów”. W drugim zdaniu "przeciwnicy gejów” są już określeni obraźliwie, stają się homofobami. Oko właściwie sam stosuje to etykietujące określenie, by wywołać w grupie docelowej przekonanie, że jeśli sprzeciwiają się prawom politycznym dla społeczności homoseksualnej, są zaklasyfikowani jako „homofoby” i grozi im zamknięcie w getcie czy więzieniu i bycie współczesnym Żydem, ofiarą ogromnej przemocy i terroru, który jest podkreślany zakładaną przez autora wypowiedzi jednolitością, stanowczością sądów środowiska mniejszościowego oraz jego wiarą we własną nieomylność. Ta ostatnia cecha, przypisana przez autora grupie określonej jako opozycyjna, może nosić znamiona projekcji. W żadnym z tekstów nie dostrzegłam bowiem fragmentów, w których Dariusz Oko wyraziłby choćby cień wątpliwości wobec słuszności własnej racji.

W Holandii już planuje się utworzenie gett dla "homofobów”, czyli przeciwników gejów. Homofoby mają być zamykani w gettach i więziach jak kiedyś Żydzi. W imię jedynie słusznej, arcypostępowej ideologii gender. Takie jest nastawienie ludzi, którzy chcą dominować, którzy pragną nad nami zapanować. Takie będą ich kolejne kroki. Trzeba wiedzieć, że ktoś, kto dziś popiera homozwiązki, jutro będzie musiał popierać homoadopcję, później zakaz mówienia „mama” i „tata”, a następnie więzienie dla każdego, kto wypowie zdanie krytyki na temat gejów. Trzeba zresztą powiedzieć, że w ten sposób przypisują sobie oni cechy boskie, bo tylko Boga nie można krytykować 25 .

Taki sposób przedstawiania oponentów ideologicznych przypomina wykorzystanie mechanizmu pogardliwych uprzedzeń, który jest zmodyfikowaną wersją mechanizmu kozła ofiarnego. Zwolennicy gender studies czy homoseksualiści są przede wszystkim przedstawiani jako grupa silna i groźna. W celu zlikwidowania wszelkich empatycznych uczuć wobec wymienianych środowisk, kreuje się ich obraz tak, by odbiorcy ustalili sobie

25 Tamże. 
trwałe połączenia skojarzeniowe pomiędzy wizerunkiem wskazanej grupy i totalitarnych przywódców, morderców, przestępców, prześladowców.

Peter Glick wyjaśniający wskazany mechanizm stwierdza, że właśnie retoryczna kreacja Żydów przedstawianych jako osoby, z którymi nie można się zidentyfikować, groźne i rywalizujące z narodem niemieckim, była jednym z kluczowych dyskursów konstytuujących usprawiedliwienie i uprawomocnienie dla przemocy wobec tej grupy etnicznej26. Glick zauważa, że dyskurs ten stał się popularny ze względu na rosnącą frustrację (nie indywidualną, ale grupową związaną ze zmianą statusu finansowego, politycznego, socjalnego społeczności). Wydaje się, że sytuacja, do której odwołuje się Dariusz Oko nie ma takiego samego statusu, jak rzeczywistość Rzeszy na początku XX wieku, ponieważ grupa docelowa, do której odwołuje się autor nie jest zespolona wokól jednoznacznie określanego wydarzenia bądź zespołu wydarzeń, które mogłyby odwoływać się do podzielanej frustracji. Jednakże, wierząc w wizję kreowaną przez Oko można by zakładać, że grupa ta niewątpliwie może się solidaryzować w statusie ofiary prześladowań. Dariusz Oko porównuje trudności współczesnych katolików z doświadczeniami osób prześladowanych przez reżim nazistowski i komunistyczny.

Biorąc pod uwagę liczbę obecnych $\mathrm{w}$ tekście wspominanego autora nawiązań do perspektywy życia katolików prześladowanych w czasach PRL, można postawić hipotezę, że zmiana statusu wspólnoty katolickiej, utrata jej dawnej politycznej i społecznej roli staje się podzielanym doświadczeniem społeczności (zwłaszcza starszych) katolików. Odpowiedzią na ten kryzys może być próba stworzenia jedności społeczności, ukonstytuowanej na odnalezieniu innego światopoglądowego wroga.

Dariusz Oko wskazuje na negację społeczności katolickiej, przedstawia on samego siebie (jako osobę reprezentującą instytucję Kościoła) i innych reprezentujących jego środowisko jako "obiekt zaszczucia”. W artykule $\mathrm{z}$ „Polonii Christiany” występuje figura retorycznego my: „,jesteśmy poddawani praniu mózgów", rewolucja seksualna ogarnia tu całą kulturę (jest bowiem przyrównana do rewolucji kulturowej), a ateiści i zwolennicy gender studies są tu określeni „bolszewikami” oraz „animatorami rewolucji seksualnej" ${ }^{27}$. Wiele z używanych przez Oko środków stylistycznych czy retorycznych odwołuje się do historiozoficznej perspektywy dziejów Europy

${ }^{26}$ P. Glick, Jagnięta ofiarne w wilczym przebraniu. Zawistne uprzedzenia, ideologia i czynienie z Żydów kozłów ofiarnych, [w:] Zrozumieć zagładę. Społeczna psychologia Holokaustu, red. L.S. Newman, R. Erber, Warszawa 2009, s. 122.

27 D. Oko, Genderrewolucja. 
czy Polski, jednak część ze wspomnianych metafor i porównań odnosi się także do konglomeratu metaforyki konsumpcyjno-ateistycznej28.

Trudno w pełni zrozumieć znaczenie ateizmu, o którym pisze autor przywołując zbiór totalitarnych przywódców, spośród których wielu wchodziło w alianse z religią. Hitler odebrał religijne wykształcenie i mimo późniejszego agnostycyzmu wskazywał na zalety religijności $\mathrm{w}$ publicznych wystąpieniach ${ }^{29}$.

Z drugiej jednak strony, we wszystkich wspominanych tekstach obok metaforyki, wskazującej na wszechpotężną moc ateizmu, konsumpcjonizmu, ideologii cielesności, którą Oko widzi u swoich przeciwników ideologicznych, występuje także wskazanie na niemalże krańcową słabość tychże oponentów. Innymi słowy, to zło, które na gruncie narracji miało wszechogarniającą siłę, kilka zdań dalej okazuje się zupełnie ją tracić. Chrześcijanie czy katolicy, którzy byli nieustannie zagrożeni przez moc ateizmu, homoseksualizmu i ideologii gender stają nagle wobec bezbronności i słabości swoich przeciwników światopoglądowych. Przykładem zastosowania takiego mechanizmu jest wywiad udzielony przez Dariusza Oko „Gościowi Niedzielnemu”, w którym wspomina o homoideologii „walczącej” z chrześcijaństwem i wspieranej (wg publicysty) przez "Gazetę Wyborczą", czy nawet księdza Prusaka, którego Oko przyrównuje do komunistycznego księdza patrioty (współpracującego z reżimem). Ostatnie fragmenty tekstu przynoszą jednakże nieoczekiwaną zmianę tonu, wskazując, że homoseksualiści są osobami "schorowanymi”. Dariusz Oko powołując się na swoje 11-letnie kontakty ze środowiskiem lekarskim, przytacza, że lekarze opowiadają: ,jak bardzo osoby homoseksualne są zaburzone, jak bardzo cierpią na skutek swoich czynów. Jak są strasznie schorowane" 30 .

Bardzo istotny jest fakt umieszczenia $\mathrm{w}$ ostatniej części artykułu treści utwierdzających społeczność w przewadze nad osobami, które określone jako "chore" mogą raczej stać się przedmiotem troski (uprawomocniając przekonanie o sile i potędze chrześcijan) ${ }^{31}$.

28 Ateizm jako postawa ideologiczna implikuje, w świetle wspomnianych wypowiedzi, kulturę hedonizmu i konsumpcjonizmu. We wspominanym artykule Genderrewolucja autor stawia tezę o ateizacji przez seksualizację - tamże.

${ }^{29}$ R. Steigmann-Gall, The Holy Reich, Nazi Conceptions of Christianity, 1919-1945, Cambridge - Ohio 2004.

30 D. Oko, Homoseksualizm nie jest norma.

${ }^{31}$ Wspominany Peter Glick wskazuje, że z podobnym zjawiskiem mamy do czynienia w dyskursach nazistowskich, gdzie obok wykazywania wszechpotęgi żydowskiej pojawiają się mniej liczne, ale obecne przekonania o ich słabości czy chorobie. P. Glick, Jagnięta ofiarne w wilczym przebraniu, s. 124-125. 
We wspominanym powyżej artykule, gdzie genderideologia określana jest epidemią dżumy, postać katolickiej autorki staje się archetypicznym obrazem kobiecej wojowniczki, którą autor przyrównuje do biblijnej Estery i Judyty, Ezechiela i Jeremiasza. Kobieta ta jest wykreowana na bohaterkę indywidualną. Oko wskazuje, że potrzeba instytucji i systemowej walki z ideologią wrogą chrześcijaństwu, jednak ostatecznie czytelnik nie ma do czynienia z walką dwóch instytucji czy systemów, ale raczej z przeciwstawieniem kobiety-matki i chrześcijanki Gabriele Kuby z systemem ideologicznym. Zwycięstwo, jakie wieści Gabriele Kuby Dariusz Oko przypomina walkę Dawida z Goliatem. Oko wskazuje, że wspominana niemiecka autorka: „piórem obnażając prawdę o genderideologii, wzorem swych biblijnych poprzedniczek Estery czy Judyty, walczy o ocalenie swego narodu. Jak Ezechiel, Jeremiasz czy Izajasz wzywa do opamiętania i nawrócenia"32.

Katolicka autorka jest zrównana z biblijnymi prorokami oraz bohaterkami starotestamentalnymi, które przekroczyły ograniczenia kulturowe związane z postrzeganiem ich płci kulturowej. Niezwykle interesujące jest to, że we fragmencie pochodzącym $z$ ostatniej części artykułu autor, niejako rykoszetem, stara się odwrócić narzędzia wykorzystywane przez teolożki feministyczne, budując konstrukcję mitu samotnej wojowniczki, ukonstytuowanego właściwie nie tyle w chrześcijańskiej, ale bardziej w żydowskiej tradycji. Dariusz Oko wykorzystuje bowiem postaci starotestamentalne ${ }^{33}$, spośród których Judyta i Estera są kluczowe dla obrzędowości judaistycznej (wspominane są w czasie święta Purim oraz Chanuka).

Prawdopodobnym retorycznym celem przywołania tych postaci jest nawiązanie do jak najstarszych źródeł uprawomocniających stanowisko obecne $\mathrm{w}$ artykule oraz wpisanie idei walki chrześcijańsko-narodowej w długotrwałą historię wytrwałego i niejednokrotnie krwawego uzyskiwania spójności oraz więzi narodu wybranego. Nawiązania te są jednak bardzo niebezpośrednie i służą raczej budowaniu wizji silnej wspólnoty narodowej, wykorzystując do tego zarówno perspektywę narodowościową niemieckiej pisarki, jak i historii starotestamentalnych zmagań związanych z walkami o ziemię i ukształtowanie spójności narodowej.

Uwypuklające wprost perspektywę narodową odwołania, powiązane bądź z żydowskością, bądź z niemieckością, mogłyby nawiązywać do skojarzeń, które nie byłyby pożądane przez polskiego katolickiego publicystę,

32 D. Oko, Genderrewolucja.

33 Oczywiście Stary Testament stanowi ważny, także dla chrześcijaństwa, tekst, jednakże bardzo interesujący jest fakt wykorzystania jedynie starotestamentalnych postaci, bez wspominania o jakiejkolwiek bohaterce czy bohaterze nowotestamentalnym. 
który zapewne dążył do przekonania czytelnika, że wskazywanym narodem jest naród czytelników (więc Polska), o czym może świadczyć ostateczna konkluzja domagająca się przekładu książki Gabriele Kuby na język polski. Jednakże, ich heurystyczne użycie, w celu wskazania na pożądane postawy, wpisuje się w normę dyskursywną (dla czasopisma, które w samym swoim tytule wskazuje czytelnikowi kluczowe odniesienia światopoglądowe), odwołującą się do topiki splecionych ze sobą kategorii narodowo-chrześcijańskich.

\section{Konkluzje}

Katolicki publicysta posługujący się hiperbolą, a także splecioną ze sobą topiką historyczną, konsumpcyjną oraz medykalną, wykorzystując dualistyczną metaforykę, przeciwstawia sobie własną grupę odbiorców (oraz grupę jego autoidentyfikacji) i członków mniejszości seksualnych czy przedstawicieli odmiennych poglądów na kwestie etyki seksualnej. Budując kategoryzacje, publicysta katolicki wykazuje tożsamość grup, z poglądami których polemizuje, i historycznych czy mitycznych wrogów chrześcijaństwa. Dyskurs budowany przez autora, będącego przedstawicielem jednej ze światopoglądowych formacji ideologicznych, konstruuje ideę przeciwstawienia się innej ideologii, która jest przedstawiona jako grupa budząca przerażenie i dążąca do zniszczenia grupy wiernych, katolików, chrześcijanPolaków. Analiza wypowiedzi Dariusza Oko, w świetle Krytycznej Analizy Dyskursu, ujawniła wykorzystanie mechanizmu, opisywanego przez Petera Glicka, zawistnego uprzedzenia. Głównym jego zadaniem jest przeciwstawienie sobie dwóch grup, wykazując zagrożenie i ambiwalentną postawę wobec społeczności mogącej zaszkodzić tożsamościowej jedności i dobrostanowi grupy docelowej.

\section{BIBLIOGRAFIA}

Althusser L., Positions, Editions sociales, Paris 1976 (polski przekł. A. Staroń na łamach internetowego czasopisma: http:/ / www.nowakrytyka.pl/spip.php?article374, 2010).

Anderson B., Wspólnoty wyobrażone, rozważania o źródłach i rozprzestrzenianiu się nacjonali$z m u$, przekł. S. Amsterdamski, Społeczny Instytut Wydawniczy, Fundacja im. Stefana Batorego, Kraków 1997.

Appadurai A., Strach przed mniejszościami. Esej o geografii gniewu, przekł. M. Buholc, Wydawnictwo Naukowe PWN, Warszawa 2009. 
Benedykt XVI, Encyklika Caritas in veritate Ojca Świętego Benedykta XVI do biskupów, prezbiterów, diakonów, do osób konsekrowanych i wszystkich wiernych świeckich o integralnym rozwoju ludzkim w miłości i prawdzie, Wydawnictwo Dehon, Kraków 2009.

Duszak A., Fairclough N. (red.), Krytyczna analiza dyskursu. Interdyscyplinarne podejście do komunikacji społecznej, Wydawnictwo Universitas, Kraków 2008.

Fairclough N., Language and power, Longman Group UK, Essex 1989.

Fairclough N., Analysing Discourse Textual Analysis for social research, Routledge, London New York 2003.

Foucault M., Nadzorować i karać. Narodziny więzienia, Fundacja Aletheia, Warszawa 1998.

Glick P., Jagnięta ofiarne w wilczym przebraniu. Zawistne uprzedzenia, ideologia i czynienie z Żydów kozłów ofiarnych, [w:] Zrozumieć zagładę. Społeczna psychologia Holokaustu, red. L.S. Newman, R. Erber, Wydawnictwo Naukowe PWN, Warszawa 2009.

Jan Paweł II, List apostolski Novo millennio ineunte Ojca Świętego Jana Pawła II do biskupów, duchowieństwa i wiernych na zakończenie wielkiego jubileuszu roku 2000, Wydawnictwo Św. Stanisława BM Archidiecezji Krakowskiej, Kraków 2001.

Krytyczna Analiza Dyskursu. Interdyscyplinarne podejście do komunikacji społecznej, red. A. Duszak, N. Fairclough, Wydawnictwo Universitas, Kraków 2008.

Oko D., Dziesięć argumentów przeciw, „Gazeta Wyborcza” z 28-29 maja 2005.

Oko D., Homoseksualizm nie jest norma, "Gość Niedzielny", 2009, 37 http://gosc.

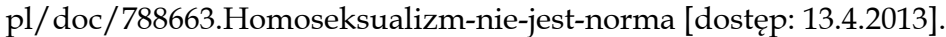

Oko D. Genderrewolucja, „Polonia Christiana” z marca/kwietnia 2013, http://www. pismo.poloniachristiana.pl/Genderrewolucja,33,0,996,1,PCH,numer.html] [dostęp: 18.3.2001].

Oko D., Homolobby przypisuje sobie cechy boskie, http://www.fronda.pl/a/ks-oko-dlafrondapl-homolobby-przypisuje-sobie-cechy-boskie,26501.html [dostęp: 18.3.2013].

Rorty R., Ironia, przygodność i solidarność, przekł. W.J. Popowski, Wydawnictwo Spacja, Warszawa 1996.

Steigmann-Gall R., The Holy Reich, Nazi Conceptions of Christianity, 1919-1945, Kent State University, Cambridge University Press, Cambridge - Ohio 2004.

Wiszowaty M.M., Regulacja prawna lobbingu na świecie. Historia, elementy, stan obecny, Wydawnictwo Sejmowe, Warszawa 2008. 